Finanse, Rynki Finansowe, Ubezpieczenia nr 3/2017 (87), cz. 1

\title{
Rozwój i doskonalenie jakości audytu wewnętrznego w jednostkach zainteresowania publicznego
}

\author{
Elżbieta Izabela Szczepankiewicz*
}

\begin{abstract}
Streszczenie: $\mathrm{Cel}$ - W artykule omówiono rozwój i cele audytu wewnętrznego oraz doskonalenie jakości jego usług w jednostkach zainteresowania publicznego.

Metodologia badania - Analiza krytyczna literatury, standardów i przepisów prawnych, metoda dedukcyjna oraz synteza wniosków z analizy.

Wynik - Przedstawiono wyniki badań ankietowych na temat jakości audytu wewnętrznego w wybranych jednostkach zainteresowania publicznego w województwie wielkopolskim.

Oryginalność/wartość - Przedstawione wyniki badań mogą stanowić asumpt do dalszych zaawansowanych badań nad zagadnieniami pomiaru i doskonalenia jakości audytu wewnętrznego w różnych jednostkach.
\end{abstract}

Słowa kluczowe: audyt wewnętrzny, jakość audytu, jednostki zainteresowania publicznego

\section{Wprowadzenie}

W literaturze krajowej aspekty pomiaru efektywności i doskonalenia jakości audytu wewnętrznego w jednostkach zainteresowania publicznego były niezwykle rzadko podejmowane. Nieco więcej opracowań naukowych, zawierających pewne aspekty z tego zakresu, można zauważyć w odniesieniu do jednostek sektora finansów publicznych. Publikowane w ostatnich latach prace na temat pomiaru efektywności i doskonalenia jakości audytu wewnętrznego dowodzą, że temat ten jest niezwykle istotny zarówno dla jednostek sektora finansów publicznych (Bednarek, 2015; Zaleska, 2015; Nadolna, 2016; Szczepankiewicz, Młodzik, 2016), jak i innych podmiotów, w których przeprowadza się audyt wewnętrzny. Zwłaszcza po ostatnim kryzysie finansowym jest on ważny dla jednostek zainteresowania publicznego. Niestety w polskim piśmiennictwie niezwykle rzadko spotyka się informacje na temat roli, funkcji i jakości audytu wewnętrznego w jednostkach zainteresowania publicznego (Wróblewska, 2010; Mikołajczyk, Krawczyk, 2010; Bielińska-Dusza, 2011; Szczepankiewicz, Kiedrowska, 2011; Szczepankiewicz, 2011; Szczepankiewicz, 2012a; Szczepankiewicz, 2012b; Bednarek, 2014; Roszewski, Andrusiewicz, 2014; Szczepankiewicz, 2014; Sawicka, Stronczek, 2015). Zachodni badacze znacznie wcześniej niż polscy zajmowali się tymi zagadnieniami i literatura jest znacznie bogatsza, co potwierdzają

\footnotetext{
* dr Elżbieta Izabela Szczepankiewicz, Uniwersytet Ekonomiczny w Poznaniu, Wydział Zarządzania, Katedra Rachunkowości, e-mail: elzbieta.szczepankiewicz@ue.poznan.pl.
} 
przykłady, m.in. Soh, Martinov-Bennie (1986); Chrostopher, Sarens, Leung (1988), Nagy, Cenker (2002); Pickett (2005); Kagerman, Kinney, Kuting, Weber (2008); Lin, Pizzini, Vargus, Barthan (2011).

Celem artykułu jest omówienie rozwoju audytu wewnętrznego w jednostkach zainteresowania publicznego, a także aspektów związanych z doskonaleniem jakości audytu wewnętrznego. W opracowaniu opisano dobre praktyki w zakresie doskonalenia jakości audytu wewnętrznego, rekomendowane przez IIA, a także przedstawiono wyniki badań ankietowych, które przeprowadzono wśród kadry kierowniczej w wybranych jednostkach funkcjonujących w województwie wielkopolskim.

\section{Rozwój i rola audytu wewnętrznego w jednostkach zainteresowania publicznego}

W Polsce audyt wewnętrzny w sektorze finansów publicznych funkcjonuje od 2002 roku, a w innych sektorach upowszechniał się w latach następnych ${ }^{1}$. Funkcjonowanie audytu wewnętrznego w jednostkach sektora finansów publicznych jest ściśle regulowane przepisami prawa i standardami. Dla jednostek funkcjonujących poza sektorem finansów publicznych do dziś nie ustanowiono formalnych regulacji w tym zakresie. Jedynie w jednostkach zainteresowania publicznego, ale tylko niektórych z sektora finansowego, w podstawowych przepisach regulujących ich organizację, wprowadzono wymóg prowadzenia audytu wewnętrznego ${ }^{2}$.

Obecnie tylko w bankach komercyjnych, zakładach ubezpieczeń i reasekuracji oraz funduszach inwestycyjnych i towarzystwach nimi zarządzających istnieje prawny obowiązek przeprowadzania audytu wewnętrznego. Zapisy w tym zakresie pojawiły się w prawie bankowym w 2008 roku (Ustawa z dnia 29 sierpnia 1997 r.), prawie ubezpieczeniowym w 2013 roku (Ustawa z dnia 11 września 2015 r.) oraz rozporządzeniu o warunkach prowadzenia działalności przez towarzystwa funduszy inwestycyjnych w 2013 roku (Rozporządzenie z dnia 30 kwietnia 2013 r.). Należy jednak podkreślić, że ustawodawca w żadnym z tych aktów ani innych przepisach wykonawczych dotychczas nie określił szczegółowych reguł organizacji i prowadzenia audytu wewnętrznego w tych jednostkach. Również Komisja Nadzoru Finansowego nie wydała żadnych wytycznych w tym zakresie, poza wytycznymi o organizacji komitetów audytu (Rekomendacje..., 2010), które ogłoszono w związku z obowiązkiem powoływania komitetów audytu w większości jednostek zainteresowania publicznego po nowelizacji ustawy o biegłych rewidentach w 2009 roku.

W Polsce nadal nie ma formalnego obowiązku prowadzenia audytu wewnętrznego w takich jednostkach zainteresowania publicznego jak: fundusze emerytalne i towarzystwa nimi zarządzające (Ustawa z dnia 28 sierpnia1997 r.), banki spółdzielcze i banki je zrzeszające

\footnotetext{
${ }^{1}$ Jedyny wyjątek w tym zakresie stanowiły banki, które powoływały komórki audytu wewnętrznego lub przekształcały je z komórek kontroli/rewizji wewnętrznej już pod koniec lat 90. XX w.

${ }^{2}$ Artykuł powstał w ramach międzyuczelnianego projektu naukowego nr 51109-XX5 „Teoretyczne i praktyczne aspekty oceny funkcji audytu wewnętrznego w sektorze publicznym” zarejestrowanym w UE w Poznaniu.
} 
(Ustawa z dnia 7 grudnia 2000 r.), spółki notowane na giełdzie i innych. Jednak wiele z tych jednostek fakultatywnie przeprowadza audyt wewnętrzny.

Jednostki, które dobrowolnie utworzyły komórki audytu wewnętrznego, początkowo wdrażały własne regulacje opisujące funkcjonowanie audytu w danej jednostce i polegało to na dobrych praktykach publikowanych przez różne organizacje. Wiele z nich w późniejszym okresie przyjęło do praktyki Międzynarodowe Standardy Profesjonalnej Praktyki Audytu Wewnętrznego, w wersji przetłumaczonej na język polski w 2001 roku przez Instytut Audytorów Wewnętrznych (Institute of Internal Auditors - IIA), zwane dalej Standardami IIA (Międzynarodowe Standardy..., 2001).

Zgodnie ze Standardami IIA, podstawowym celem audytu wewnętrznego jest świadczenie niezależnych i obiektywnych usług zapewniających i doradczych $w$ jednostce, w której jest on prowadzony. $Z$ efektywnym funkcjonowaniem audytu wewnętrznego w jednostce, niezależnie od sektora czy branży, wiąże się potrzeba prowadzenia oceny i doskonalenia jego jakości. W jednostkach sektora finansów publicznych przewidziano tę potrzebę już w 2003 roku. Pozostałe jednostki, działające poza sektorem finansów publicznych, zazwyczaj korzystają z własnych regulacji wewnętrznych w tym zakresie albo doskonalą jakość funkcjonowania audytu, według wytycznych zawartych w międzynarodowych Standardach IIA (Definicja audytu..., 2016).

Zgodnie ze Standardem IIA 1300 kierownik komórki audytu wewnętrznego powinien opracować i realizować program zapewnienia i poprawy jakości audytu, który obejmuje wszystkie aspekty jego funkcjonowania ${ }^{3}$, a także monitorować w sposób ciągły jego efektywność. Interpretacja IIA do Standardu 1300 wskazuje, że celem tego programu jest między innymi ocena wydajności i skuteczności audytu wewnętrznego oraz identyfikacja możliwości poprawy w tym zakresie. Należy podkreślić, że w nowej wersji Standardów IIA obowiązującej od września 2016 roku zaleca się, aby kierownik komórki audytu zachęcał radę nadzorczą lub inny organ nadzorujący w jednostce do nadzorowania programu zapewnienia i poprawy jakości audytu wewnętrznego.

Zdaniem autorki, cele funkcjonowania programu zapewnienia i doskonalenia jakości audytu wewnętrznego w każdej jednostce, niezależnie od sektora czy branży, powinny być skorelowane z celami funkcjonowania audytu. Zatem program zapewnienia i doskonalenia jakości powinien również przysparzać wartości dodanej nie tylko dla jednostki, w której audyt jest prowadzony, ale również dla samej komórki audytu wewnętrznego.

\section{Rekomendacje i dobre praktyki w zakresie doskonalenia audytu wewnętrznego}

Instytut Audytorów Wewnętrznych od 20 lat przeprowadza, na prośbę komórek audytu wewnętrznego $\mathrm{w}$ różnych organizacjach na świecie, zewnętrzne oceny programów

\footnotetext{
${ }^{3}$ Zgodnie ze Standardem 1300 - Program zapewnienia i poprawy jakości (Definicja audytu..., 2016).
} 
zapewnienia jakości. Obserwacje i rekomendacje IIA w tym zakresie mogą być przydatne dla audytu wewnętrznego w różnych jednostkach na świecie, niezależnie od sektora czy branży, przy przygotowywaniu własnych programów zapewnienia i doskonalenia jakości oraz $\mathrm{w}$ trakcie przeprowadzania samooceny przez komórki audytu wewnętrznego. Obserwacje IIA wskazują zarówno najczęściej występujące problemy, które pojawiały się w komórkach audytu wewnętrznego, jak i stanowią wskazówkę co do sposobu przeprowadzania ocen zewnętrznych. Mogą one dotyczyć również audytu wewnętrznego w wielu polskich jednostkach.

W tabeli 1 przedstawiono wybrane obserwacje i rekomendacje zespołów oceniających z IIA.

IIA wskazuje również zbiór wybranych najlepszych praktyk dotyczących audytu wewnętrznego, które zidentyfikowały zespoły IIA podczas ocen zewnętrznych w różnych organizacjach na świecie. Najlepsze praktyki audytu wewnętrznego to (Wytyczne w zakresie programu..., 2012; Knowledge Report..., 2010; Professionalism In Practice.., 2010; Pitt, 2014):

1. Włączenie kierownictwa jednostki w proces analizy ryzyka przy rocznej analizie oraz przy poszczególnych zadaniach audytowych.

2. Wykorzystanie „burzy mózgów” podczas planowania zadań i sporządzania raportów z nich, co wzmacnia te elementy procesu.

3. Cykliczne (np. comiesięczne) spotkania pracowników komórek audytu wewnętrznego z kierownictwem, aby uświadamiać istotność procesu nadzoru organizacyjnego, zarządzania ryzykiem, roli i zadań audytu wewnętrznego, słabych i silnych stron systemu kontroli wewnętrznej.

4. Wprowadzenie wewnętrznych narzędzi oceny jakości audytu wewnętrznego po zakończonych zadaniach audytowych, w tym: każdorazowa weryfikacja dokumentacji z zadania, ustalenie kryteriów oceny wykonywanych zadań, porównanie z najlepszymi praktykami.

5. Korzystanie z punktowej oceny działalności audytu wewnętrznego oraz przedstawianie wyników realizacji programu.

6. Uczestnictwo w stowarzyszeniach związanych z audytem, udział audytorów jako wolontariuszy w zewnętrznych ocenach jakości audytu wewnętrznego prowadzonych $\mathrm{w}$ formie przeglądów partnerskich.

7. Wdrożenie krótko- i długoterminowych planów rotacji pracowników audytu wewnętrznego.

8. Przygotowanie broszury opisującej cel, zakres (świadczone usługi), odpowiedzialność oraz korzyści z audytu wewnętrznego dla wszystkich pracowników jednostki - marketing działań audytu wewnętrznego.

9. Przygotowanie szkoleń dla wszystkich pracowników jednostki na temat znaczenia systemu kontroli wewnętrznej i audytu wewnętrznego. 
10. Świadczenie usług doradczych dla kierownictwa jednostki przy wdrażaniu zmian organizacyjnych i aktualizowania systemu kontroli wewnętrznej.

11. Korzystanie z systemów informatycznych wspomagających audytu wewnętrznego.

12. Utworzenie bazy wniosków, zaleceń i rekomendacji audytu wewnętrznego, biegłego rewidenta i innych kontrolerów.

\section{Tabela 1}

Obserwacje i rekomendacje odnoszące się do Standardów proponowane przez IIA

\begin{tabular}{|c|c|c|}
\hline Temat obserwacji & $\begin{array}{l}\text { Standard } \\
\text { audytu }\end{array}$ & Rekomendacja IIA \\
\hline 1 & 2 & 3 \\
\hline $\begin{array}{l}\text { 1. Brak corocznego aktuali- } \\
\text { zowania karty audytu }\end{array}$ & $\begin{array}{l}\text { Standard } \\
1000\end{array}$ & $\begin{array}{l}\text { karta audytu powinna być okresowo oceniana pod kątem zgodności } \\
\text { z obowiązującymi przepisami, Standardami IIA, wewnętrznymi } \\
\text { procedurami oraz celami i planami/programami organizacji; naj- } \\
\text { lepsze praktyki określają, że ocena taka powinna być wykonywana } \\
\text { corocznie, aby karta odzwierciedlała naturę oraz zakres aktualnych } \\
\text { zadań audytu wewnętrznego; proces oceny karty można połączyć } \\
\text { z planowaniem rocznym lub roczną analizą ryzyka; po każdej } \\
\text { aktualizacji karta audytu powinna zostać zaakceptowana przez } \\
\text { kierownika jednostki }\end{array}$ \\
\hline
\end{tabular}

2. Niewystarczająca wiedza Standard audytora wewnętrznego 1210

z zakresu zarządzania organizacją oraz technologii informatycznych

3. Brak sformalizowanych programów zapewnienia i poprawy jakości, a także brak w istniejących programach niektórych istotnych elementów, jak np. okresowych ocen audytu wewnętrznego wykonywanych drogą samooceny lub przez osobę z organizacji z odpowiednią wiedzą z zakresu audytu wewnętrznego

\begin{tabular}{lll}
\hline $\begin{array}{l}\text { 4. Brak opracowanych } \\
\text { formalnych modeli }\end{array}$ & Standard & zarządzający audytu wewnętrznego musi opracowywać plany na \\
przeprowadzania analizy & 2010 & podstawie analizy ryzyka, określające zgodne z celami organizacji \\
ryzyka & & priorytety dla działań audytu wewnętrznego; zarządzający audytu \\
& wewnętrznego wykorzystuje system zarządzania ryzykiem w or- \\
& ganizacji, w tym poziomy apetytu na ryzyko, ustanowione przez \\
& kierownictwo dla różnych zadań i części organizacji, jeśli taki sys- \\
& tem nie istnieje, zarządzający audytu wewnętrznego wykorzystuje \\
& własną ocenę ryzyka, po konsultacjach z kierownictwem wyższego \\
& szczebla i radą \\
\hline
\end{tabular}
Standardy
taka ocena powinna być przeprowadzana przynajmniej raz na rok, 1300,1311 audytu wewnętrznego takich jak: cykl audytu, zadowolenie interesa- riuszy audytu, które mogą być na bieżąco monitorowane kwalifikacje niezbędne do wykonywania swoich obowiązków audytorzy powinni mieć lub zdobyć wiedzę i umiejętności oraz inne 


\begin{tabular}{lll}
\hline 1 & 2 & 3 \\
\hline 5. Brak formalnych & Standard & ustalenie takich procedur oraz ich spisanie, zwłaszcza w większych \\
procedur audytu we- & 2040 & komórkach audytu wewnętrznego, pozwala na skupienie się na \\
wnętrznego & & realizacji konkretnych zadań, procedury mają przede wszystkim \\
& & służyć lepszemu zarządzaniu komórką audytu wewnętrznego, pełnią \\
& również istotną funkcję edukacyjną dla nowych pracowników komó- \\
& rek audytu wewnętrznego; opis procedur audytu może funkcjonować \\
& pod nazwą Księga procedur audytu wewnętrznego \\
\hline
\end{tabular}

\begin{tabular}{|c|c|c|}
\hline $\begin{array}{l}\text { 6. Proces nadzoru orga- } \\
\text { nizacyjnego nie jest } \\
\text { brany pod uwage przy } \\
\text { planowaniu rocznym }\end{array}$ & $\begin{array}{l}\text { Standard } \\
2110\end{array}$ & $\begin{array}{l}\text { zgodnie ze Standardami IIA audytorzy powinni: } \\
\text { - oceniać czy cele nadzoru organizacyjnego są realizowane, } \\
\text { - badać zgodność funkcjonowania organizacji z polityką nadzoru } \\
\text { organizacyjnego, } \\
\text { - badać włączenie nadzoru organizacyjnego we wszystkie działania } \\
\text { operacyjne }\end{array}$ \\
\hline $\begin{array}{l}\text { 7. Analiza ryzyka } \\
\text { przeprowadzana na } \\
\text { potrzeby planowania } \\
\text { rocznego nie jest połą- } \\
\text { czona z oceną ryzyka } \\
\text { w organizacji }\end{array}$ & $\begin{array}{l}\text { Standard } \\
2120\end{array}$ & $\begin{array}{l}\text { może to powodować, że praca audytorów w niewielkim stopniu } \\
\text { przekłada się na działalność organizacji, należy dążyć, aby w proces } \\
\text { analizy ryzyka włączać osoby odpowiedzialne za zarządzanie ryzy- } \\
\text { kiem w organizacji (niezależnie od tego czy w organizacji istnieje } \\
\text { formalny proces zarządzania ryzykiem czy też nie) i ustalić, jakie } \\
\text { cele są dla organizacji najistotniejsze }\end{array}$ \\
\hline $\begin{array}{l}\text { 8. Ryzyka związane } \\
\text { z systemami informa- } \\
\text { cyjnymi nie są brane } \\
\text { pod uwagę w procesie } \\
\text { analizy ryzyka }\end{array}$ & $\begin{array}{l}\text { Standard } \\
2120 \\
2201\end{array}$ & $\begin{array}{l}\text { ryzyka związane z systemami informacyjnymi powinny być } \\
\text { uwzględniane z uwagi na ich istotne znaczenie dla każdej orga- } \\
\text { nizacji }\end{array}$ \\
\hline $\begin{array}{l}\text { 9. Brak wzorów doku- } \\
\text { mentów przygotowy- } \\
\text { wanych przez audytu } \\
\text { wewnętrznego }\end{array}$ & $\begin{array}{l}\text { Standardy } \\
2240,2330\end{array}$ & $\begin{array}{l}\text { należy opracować standardy tworzenia dokumentacji w tym: wzory } \\
\text { dokumentów, wymogi dotyczące dokumentowania, numerowania } \\
\text { oraz nanoszenia odnośników, które będą na tyle elastyczne, aby } \\
\text { mogły być wykorzystywane we wszystkich rodzajach audytów, } \\
\text { badań i ocen }\end{array}$ \\
\hline $\begin{array}{l}\text { 10. Zbyt późne, w ocenie } \\
\text { osób dokonujących } \\
\text { ocen zewnętrznych, jak } \\
\text { i odbiorców audytu, } \\
\text { przekazywanie sprawoz- } \\
\text { dań z zadań audytowych }\end{array}$ & $\begin{array}{l}\text { Standard } \\
2420\end{array}$ & $\begin{array}{l}\text { sprawozdanie powinno być aktualne i dlatego też czas pomiędzy } \\
\text { zakończeniem zadnia oraz przekazaniem sprawozdania powinien } \\
\text { być możliwie jak najkrótszy }\end{array}$ \\
\hline $\begin{array}{l}\text { 11. Brak formalnych } \\
\text { planów doskonalenia } \\
\text { zawodowego audytorów } \\
\text { i niekorzystanie z rotacji } \\
\text { pracowników w ramach } \\
\text { organizacji. Plany szko- } \\
\text { leniowe nie korespon- } \\
\text { dują z ścieżkami kariery } \\
\text { zawodowej }\end{array}$ & $\begin{array}{l}\text { Standardy } \\
1210,1230 \\
2020\end{array}$ & $\begin{array}{l}\text { plany szkoleniowe powinny korespondować z ścieżkami kariery } \\
\text { zawodowej, zarówno plany doskonalenia, jak i wewnętrzna rotacja } \\
\text { pozwalają na zdobywanie doświadczenia przez kierownictwo we } \\
\text { wszystkich aspektach działania organizacji oraz zapewniają pogłę- } \\
\text { bianie wiedzy audytorów z zakresu zarządzania }\end{array}$ \\
\hline $\begin{array}{l}\text { 12. Nieefektywna komuni- } \\
\text { kacja }\end{array}$ & $\begin{array}{l}\text { Standardy } \\
1111 \\
2020 \\
2060 \\
2110 \\
2400-2440\end{array}$ & $\begin{array}{l}\text { nieefektywna komunikacja może być rozpatrywana na dwóch płasz- } \\
\text { czyznach: w ramach komórki audytu wewnętrznego oraz z odbior- } \\
\text { cami audytu; należy pamiętać, że ta druga płaszczyzna komunikacji } \\
\text { nie będzie dobrze funkcjonować bez bezpośrednich spotkań, które } \\
\text { pozwalają na lepsze zrozumienie roli i zadań audytu wewnętrznego } \\
\text { przez odbiorców audytu z jednej strony oraz na lepsze poznanie } \\
\text { potrzeb odbiorców audytu z drugiej }\end{array}$ \\
\hline
\end{tabular}

Źródło: opracowanie własne na podstawie Wytyczne w zakresie programu... (2012); Definicja audytu... (2016). 
Studia literaturowe wskazują, że w zachodnich organizacjach w przypadku dużych komórek audytu wewnętrznego lub komórek funkcjonujących w złożonym środowisku (np. liczne komórki organizacyjne, oddziały, filie, jednostki podległe, w których prowadzony jest audyt wewnętrzny albo w grupie kapitałowej), zarządzający ustanawiają w komórce audytu wewnętrznego formalne, oddzielne, niezależne jednoosobowe lub wieloosobowe stanowisko do spraw zapewnienia jakości audytu. W praktyce, w zależności od przyjętego rozwiązania, osoba pełniąca tę funkcję albo wykonuje wszystkie obowiązki związane z programem zapewnienia i poprawy jakości, albo jedynie zarządza i monitoruje te działania.

\section{Charakterystyka próby badawczej}

Próba badawcza jednostek do przeprowadzenia pilotażowych badań własnych autorki obejmowała kadrę kierowniczą oraz dokumentację wewnętrzną wybranych jednostek zainteresowania publicznego z województwa wielkopolskiego. Badaniami ankietowymi oraz studium dokumentacji wewnętrznej objęto następujące jednostki:

- banki komercyjne,

- bank zrzeszający banki spółdzielcze ${ }^{4}$,

- zakłady ubezpieczeń,

- towarzystwa funduszy inwestycyjnych,

- towarzystwa funduszy emerytalnych,

- spółki notowane na giełdzie i inne spółki prawa handlowego.

Poszczególne typy jednostek zainteresowania publicznego zostały scharakteryzowane pod względem trzech kryteriów (tab. 2):

- przepisów wyznaczających obowiązek prowadzenia audytu wewnętrznego,

- obowiązku stosowania standardów audytu wewnętrznego,

- organizacji funkcji audytu wewnętrznego.

\section{Tabela 2}

Charakterystyka jednostek dobranych do próby badawczej

\begin{tabular}{llll}
\hline $\begin{array}{l}\text { Sektor/rodzaj } \\
\text { podmiotu }\end{array}$ & $\begin{array}{l}\text { Przepisy wyznaczające } \\
\text { obowiązek prowadzenia } \\
\text { audytu wewnętrznego }\end{array}$ & $\begin{array}{l}\text { Obowiązek stosowania standar- } \\
\text { dów audytu wewnętrznego }\end{array}$ & $\begin{array}{l}\text { Organizacja funkcji audytu } \\
\text { wewnętrznego }\end{array}$ \\
\hline 1 & 2 & 3 & 4 \\
\hline Banki komercyjne & prawo bankowe & $\begin{array}{l}\text { brak formalnego obowiązku } \\
\text { stosowania określonych standar- } \\
\text { dów; fakultatywnie stosowane } \\
\text { Standardy IIA lub własne } \\
\text { regulacje }\end{array}$ & $\begin{array}{l}\text { komórka audytu wewnętrzne- } \\
\text { powołany komitet audytu }\end{array}$ \\
& & & \\
\hline
\end{tabular}

\footnotetext{
${ }^{4}$ W Poznaniu działa SGB-Bank SA zrzeszający ponad 200 banków spółdzielczych (ponad 40\%) w całej Polsce.
} 


\begin{tabular}{lll}
\hline 1 & 2 & 3 \\
\hline Banki spółdzielcze & brak & brak formalnego obowiązku \\
i zrzeszające & & stosowania określonych standar- \\
& & dów; fakultatywnie stosowane \\
& Standardy IIA w bankach zrze- \\
& szających lub regulacje własne
\end{tabular}

\section{4}

komórka audytu wewnętrz-

nego utworzona w banku

zrzeszającym oraz powołany

komitet audytu jak w spółkach

akcyjnych, audyt wewnętrz-

ny prowadzony w banku

zrzeszającym oraz w bankach

spółdzielczych z poziomu

banku zrzeszającego

\begin{tabular}{ll}
\hline $\begin{array}{l}\text { Zakłady ubezpie- } \\
\text { czeń }\end{array}$ & $\begin{array}{l}\text { ustawa o działalności } \\
\text { ubezpieczeniowej i re- } \\
\text { asekuracyjnej }\end{array}$ \\
\hline $\begin{array}{l}\text { Towarzystwa } \\
\text { funduszy inwesty- } \\
\text { cyjnych }\end{array}$ & $\begin{array}{l}\text { rozporządzenie w spra- } \\
\text { wie sposobu, trybu oraz } \\
\text { warunków prowadzenia } \\
\text { działalności przez TFI }\end{array}$
\end{tabular}

brak formalnego obowiązku stosowania określonych standardów; fakultatywnie stosowane Standardy IIA lub regulacje własne

komórka audytu wewnętrznego utworzona w zakładzie oraz powołany komitet audytu komórka audytu wewnętrznego utworzona w towarzystwie lub zadania audytowe prowadzone przez zarząd towarzystwa; powołany komitet audytu w towarzystwie; audyt wewnętrzny obejmuje działalność towarzystwa oraz zarządzanych przez nie funduszy inwestycyjnych

Towarzystwa brak
funduszy emery-
talnych

Spółki notowane brak
na giełdzie i inne
spółki prawa
handlowego

\begin{tabular}{l}
\hline fakultatywnie utworzona \\
komórka kontroli lub audytu; \\
brak obowiązku tworzenia \\
komitetu audytu \\
\hline fakultatywnie utworzona \\
komórka kontroli lub audytu; \\
komitet audytu powołany \\
tylko w spółkach notowanych \\
na giełdzie
\end{tabular}

Źródło: opracowanie własne.

Na podstawie przeprowadzonych badań ustalono, że interesariuszami sprawozdań audytu wewnętrznego w badanych jednostkach zainteresowania publicznego są: zarząd, kierownicy komórek audytowanych, rada nadzorcza, komitet audytu (jeśli został powołany), biegły rewident oraz inni zainteresowani.

W tabeli 3 zaprezentowano wyniki badań z uzyskanych odpowiedzi na pytanie - czy audyt wewnętrzny przyczynił się do usprawnienia działalności jednostki/wniósł wartość dodaną. Odpowiedzi uzyskano od kadry kierowniczej badanych jednostek w województwie wielkopolskim. Jednostki te posiadały własne komórki audytu wewnętrznego. Pytanie skierowano w szczególności do kierowników komórek audytowanych w obszarze finansów i rachunkowości oraz administracji jednostki.

Na podstawie przeprowadzonych badań można stwierdzić, że odpowiedź „tak” oznacza, że usługi audytu wewnętrznego, zdaniem ankietowanych, jednoznacznie przysporzyły jednostce wartości dodanej. Ankietowani byli również zobowiązani do uzasadnienia odpowiedzi „nie” oraz „trudno to ocenić”. Odpowiedź „nie” uzasadniano najczęściej stwierdzeniem, 
że audyt wewnętrzny świadczył usługi na tak niskim poziomie, że kadra kierownicza nie była w stanie wykorzystać wyników dostarczonych przez audytorów wewnętrznych do poprawy funkcjonowania komórki audytowanej w badanym obszarze, natomiast odpowiedź „trudno to ocenić” padała w przypadku, jeśli:

a) usługi audytu wewnętrznego, zdaniem ankietowanych, nie stanowiły ważnego aspektu dla prowadzenia działalności jednostki lub komórki audytowanej;

b) prowadzenie audytu wewnętrznego wynikało $\mathrm{z}$ obowiązku wyznaczonego przez określone regulacje (przepisy prawa lub regulacje wewnętrzne), ale jego wyniki nie są brane lub były rzadko brane pod uwagę przez kierownictwo;

c) wyniki audytu wewnętrznego nie zawierały istotnych wniosków i/lub znaczących rekomendacji dla badanego obszaru;

d) wyniki audytu wewnętrznego nie wniosły istotnych rekomendacji, ponieważ w badanym obszarze właściwie funkcjonuje system kontroli wewnętrznej.

\section{Tabela 3}

Czy audyt wewnętrzny przyczynił się do usprawnienia działalności jednostki/wniósł wartość dodaną

\begin{tabular}{lccc}
\hline \multirow{2}{*}{ Sektor/rodzaj badanego podmiotu } & \multicolumn{3}{c}{ Odpowiedź (\%) } \\
\cline { 2 - 4 } & tak & nie & trudno to ocenić \\
\hline Banki komercyjne & 78 & 5 & 17 \\
Bank zrzeszający banki spółdzielcze & 100 & 0 & 0 \\
Zakłady ubezpieczeń & 63 & 12 & 15 \\
Towarzystwa funduszy inwestycyjnych & 58 & 24 & 18 \\
Towarzystwa funduszy emerytalnych & 52 & 32 & 16 \\
Spółki notowane na giełdzie i inne spółki prawa handlowego & 44 & 5 & 50 \\
\hline
\end{tabular}

Źródło: opracowanie własne.

W niewielu badanych jednostkach opracowano programu zapewnienia i doskonalenia jakości audytu wewnętrznego. Programy takie opracowano w większości badanych banków komercyjnych i mniej niż połowie zakładów ubezpieczeń. Programy zapewnienia i doskonalenia jakości audytu wewnętrznego znacznie różnią się w poszczególnych jednostkach. We wszystkich analizowanych programach powtarzały się następujące aspekty:

- nadzór nad opracowaniem i wdrożeniem wewnętrznych procedur audytu wewnętrznego,

- wspieranie zarządzającego audytu wewnętrznego oraz innych pracowników audytu wewnętrznego w uzyskiwaniu bieżących informacji na temat zmian w standardach, przepisach i najlepszych praktykach wykonywania zawodu audytora wewnętrznego,

- utrzymywanie i aktualizacja kart (regulaminów) oraz procedur audytu wewnętrznego,

- utrzymywanie i aktualizacja informacji o ryzyku audytu wewnętrznego (zidentyfikowanym w komórce audytu wewnętrznego, a także związanym z procesem realizacji audytu wewnętrznego w jednostce oraz podległych filiach i oddziałach), 
- kierowanie ogólnym funkcjonowaniem systemu oceny ryzyka oraz długookresowego planowania audytu wewnętrznego (plany strategiczne, w tym obejmujące aspekty przyszłych potrzeb i rozwoju audytu),

- proces przygotowania harmonogramu zadań zapewniających i czynności doradczych oraz sprawdzanie jego realizacji,

- nadzór nad zbiorami danych i informacjami dotyczącymi realizacji zadań audytowych, działań poaudytowych i innych czynności, udostępnianych różnym interesariuszom,

- kierowanie i/lub nadzór nad zbieraniem informacji i przygotowywaniem okresowych sprawozdań audytu wewnętrznego dla kierownictwa jednostki,

- monitorowanie wszelkich działań związanych z zapewnieniem jakości i usprawnieniem funkcjonowania audytu wewnętrznego, w tym nadzór nad wewnętrznymi i zewnętrznymi ocenami jakości,

- zarządzanie wewnętrzną i zewnętrzną rekrutacją kandydatów do pracy w komórce audytu wewnętrznego,

- nadzór nad szkoleniami pracowników komórki audytu wewnętrznego, np. wybór lub opracowanie kursów szkoleniowych.

W niektórych programach opisano również takie aspekty, jak:

- dbałość o jakość audytu od strony technologicznej, w tym: procedury zakupu, utrzymywania oraz stosowania najnowszych narzędzi audytorskich i technologii informatycznych,

- prowadzenie bazy danych o rekomendacjach audytorów i planach działań wynikających z zadań audytu wewnętrznego,

- prowadzenie bazy danych o czynnościach audytorów związanych z wewnętrzną oceną audytu wewnętrznego,

- prowadzenie bazy danych o czynnościach audytorów zewnętrznych oraz innych funkcjach związanych z zewnętrzną oceną jakości audytu wewnętrznego,

- kierowanie i/lub nadzór nad zbieraniem informacji i przygotowywaniem okresowych sprawozdań audytu wewnętrznego na temat wyników wewnętrznych i zewnętrznych ocen jakości,

- nadzór nad rozwojem zawodowym pracowników komórki audytu wewnętrznego, w tym: zarządzanie procesami planowania ścieżki doskonalenia zawodowego oraz nadzór nad procesem oceny pracowników i programami rozwojowymi pracowników.

W tych jednostkach, gdzie nie było możliwości stworzenia oddzielnego stanowiska ds. zapewnienia jakości audytu wewnętrznego zazwyczaj jasno określono i przypisywano zadania $\mathrm{z}$ tego zakresu wskazanym osobom, zatrudnionym w komórce audytu wewnętrznego lub kierownikowi tej komórki. W przypadku jednoosobowych stanowisk do spraw jakości audytu audytorzy wewnętrzni zazwyczaj sami dbali o ten aspekt swojej działalności.

W przypadku jednoosobowych stanowisk do spraw jakości audytorzy wewnętrzni w badanych jednostkach wdrażali podstawowe elementy zapewnienia jakości audytu, 
wynikające ze Standardów IIA. Wówczas w programach zapewnienia i doskonalenia jakości, pojawiły się takie elementy zapewnienia jakości audytu wewnętrznego, jak:

- opracowywanie planu audytu wewnętrznego na rok następny,

- sporządzanie sprawozdania z wykonania planu audytu wewnętrznego za rok poprzedni,

- przegląd akt bieżących prowadzony we własnym zakresie, np. pod kątem sprawdzenia kompletności dokumentacji,

- prowadzenie list sprawdzających, które potwierdzały, że czynności audytora przebiegały w sposób zgodny ze standardami i przyjętymi procedurami,

- pozyskiwanie informacji zwrotnej (ankiety poaudytowe) od audytowanych, kierownika jednostki i innych zainteresowanych stron, na bieżąco po zakończonym zadaniu,

- przeprowadzanie corocznej samooceny,

- przeprowadzanie okresowej oceny zewnętrznej (co 5 lat lub częściej).

W praktyce, niezależnie od tego, ile osób było zaangażowanych w wykonywanie funkcji programu zapewnienia i poprawy jakości audytu wewnętrznego, zawsze zarządzający komórką audytu jest odpowiedzialny za realizację tego programu. Jest to zgodnie ze Standardami IIA.

\section{Uwagi końcowe}

Właściwie opracowany, wdrożony i realizowany program zapewnienia i doskonalenia jakości audytu wewnętrznego stanowi podstawę do przeprowadzania działań usprawniających funkcjonowanie audytu wewnętrznego w jednostce. Zamieszczone na stronach internetowych IIA opracowania dotyczące takich modeli i narzędzi, jak Model IA - CM, benchmarking i inne, stanowią zaawansowane instrumenty usprawniania działalności audytu wewnętrznego. Ich zastosowanie musi jednak zostać poprzedzone odpowiednimi działaniami prowadzonymi już na poziomie planowania programu zapewnienia i doskonalenia jakości audytu wewnętrznego.

W wyniku przeprowadzonej analizy standardów i wytycznych dotyczących audytu wewnętrznego (Definicja audytu..., 2016; Wytyczne do samooceny..., 2012; Wytyczne w zakresie programu..., 2012), opracowań IIA (Knowledge Report..., 2010; Professionalism In Practice..., 2010), wyżej cytowanych pozycji z literatury krajowej i zagranicznej, a także na podstawie wyników badań własnych autorki, można wskazać następujące cechy programu zapewnienia i doskonalenia jakości audytu wewnętrznego zgodne z rolą i celami audytu wewnętrznego, które należy uwzględnić na etapie jego opracowywania w jednostkach zainteresowania publicznego:

- obejmowanie wszystkich aspektów działań audytu wewnętrznego, w tym usług doradczych, 
- wyznaczenie osoby odpowiedzialnej za wszystkie działania w ramach programu, przy czym działania te powinny być realizowane przez lub pod bezpośrednim nadzorem kierownika komórki audytu wewnętrznego,

- wspieranie działań audytu wewnętrznego zmierzających do przysporzenia wartości i poprawy funkcjonowania jednostki,

- zapewnianie zgodności audytu z ustanowioną kartą (regulaminem) audytu wewnętrznego, przyjętymi standardami audytu wewnętrznego, kodeksem etyki audytora wewnętrznego oraz innymi i regulacjami obowiązującymi w danej jednostce,

- wskazanie zasad oraz narzędzi monitorowania efektywności i skuteczności audytu wewnętrznego,

- wskazanie procedur pomiaru i analizy efektywności działania audytu wewnętrznego, w tym mierników pomiaru,

- prowadzenie bieżących i okresowych ocen wewnętrznych audytu wewnętrznego (oceny poaudytowe, samoocena),

- prowadzenie oceny zewnętrznej audytu wewnętrznego dokonywanej przynajmniej raz na pięć lat,

- zobowiązanie do ujawniania najwyższemu kierownictwu jednostki (kierownikowi jednostki, zarządowi, radzie nadzorczej, komitetowi audytu lub innemu organowi nadzorującemu) wyników realizacji programu zapewnienia i doskonalenia jakości w formie sprawozdań,

- wskazanie procedury wprowadzania odpowiednich działań doskonalących jakość audytu wewnętrznego, w tym bieżących działań naprawczych, a także badania skuteczności tych działań oraz stosowania dobrych praktyk audytu wewnętrznego,

- wskazanie procedury pomiaru przysporzenia wartości dodanej, usprawnienia działalności operacyjnej jednostki, wkładu w proces doskonalenia nadzoru organizacyjnego, zarządzania ryzykiem i kontroli wewnętrznej.

Z uwagi na to, że dla jednostek zainteresowania publicznego ustawodawca nie ogłosił żadnych regulacji dotyczących zasad organizacji audytu wewnętrznego, standardów ani wytycznych, kierownictwo tych jednostek, a w szczególności komórki audytu wewnętrznego powinny rozważyć możliwość wykorzystania wytycznych opracowanych dla sektora finansów publicznych takich, jak: Wytyczne do samooceny audytu wewnętrznego $w$ jednostkach sektora finansów publicznych (2012) oraz Wytyczne w zakresie programu zapewnienia i poprawy jakości (2012). Wytyczne w tych dokumentach są na tyle uniwersalne, że wyznaczają podstawowy kierunek doskonalenia funkcji audytu wewnętrznego w dowolnej jednostce, niezależnie od sektora i branży, w której dana jednostka funkcjonuje.

Zdaniem autorki, przedstawione rezultaty badawcze mogą stanowić asumpt do dalszych zaawansowanych badań nad złożonymi zagadnieniami pomiaru i doskonalenia jakości audytu wewnętrznego w jednostkach zainteresowania publicznego. 


\section{Literatura}

Bednarek, P. (2014). Samoocena audytu wewnętrznego w Polsce: stan wiedzy i kierunki dalszych badań. Prace Naukowe Uniwersytetu Ekonomicznego we Wrocławiu, 343, 31-41.

Bednarek, P. (2015). Samoocena $w$ audycie wewnętrznym jednostek sektora finansów publicznych. Wrocław: Wydawnictwo Uniwersytetu Ekonomicznego we Wrocławiu.

Bielińska-Dusza, E. (2011). Analysis of internal audit functioning in Poland - empirical research findings. Business, Management and Education, 9 (2), 236-247.

Christopher, J., Sarens, G., Leung, P. (1988). A critical analysis of the independence of the internal audit function: evidence from Australia. Accounting, Auditing \& Accountability Journal, 22 (2), 200-220.

Definicja Audytu Wewnętrznego, Kodeks Etyki oraz Międzynarodowe Standardy Praktyki Zawodowej Audytu Wewnętrznego (2016). The Institute of Internal Auditors, USA. Warszawa: Tłum. IIA - Polska. Pobrane z: http:// www.iia.org.pl (16.03.2017).

Kagerman, H., Kinney, W., Kuting, K., Weber, C-P. (2008). Internal Audit Handbook. Berlin: Springer.

Knowledge Report. Attributes of Highly Effective Quality Assurance And Improvement Programs (2010). The Institute of Internal Auditors, USA. Pobrane z: http://www.theiia.org/download.cfm?file=66960 (28.05.2017).

Lin, S., Pizzini, M., Vargus, M., Bardhan, I.R. (2011). The Role of the Internal Audit Function in the Disclosure of Material Weaknesses. The Accounting Review, 86 (1), 287-322.

Międzynarodowe Standardy Profesjonalnej Praktyki Audytu Wewnętrznego (2001). The Institute of Internal Auditors, USA. Tłum. IIA - Polska, Warszawa 2006. Pobrane z: http://www.iia.org.pl (16.08.2006).

Mikołajczyk, B., Krawczyk, M. (2010). Audyt wewnętrzny w teorii i praktyce ubezpieczeniowej. Warszawa: PWE.

Nadolna, B. (2016). Balanced scorecard jako narzedzie oceny dokonań audytu wewnętrznego w jednostkach sektora finansów publicznych. Finanse, Rynki Finansowe, Ubezpieczenia, 6/1 (84), 333-346. DOI: 10.18276/ frfu.2016.84/1-29.

Pickett, K.H. (2005). The Essential Handbook of Internal Auditing. Chichester: John Wiley \& Sons, Ltd.

Pitt, S.A. (2014). Internal Audit Quality, Developing a Quality Assurance and Improvement Program. NJ: Wiley, Hoboken.

Professionalism In Practice. External quality assessments (2010). The Institute of Internal Auditors, USA. Pobrane z: http://www.theiia.org/download.cfm?file=89205 (18.03.2010).

Rekomendacje dotyczące funkcjonowania Komitetu Audytu (2010). Warszawa: Urząd Komisji Nadzoru Finansowego.

Roszewski, Z., Andrusiewicz, G. (2014). Audyt wewnętrzny w zintegrowanym systemie zarządzania ryzykiem w zakładach ubezpieczeń. Prawo Asekuracyjne, 3 (80), 117-137.

Rozporządzenie Ministra Finansów z dnia 30 kwietnia 2013 r. w sprawie sposobu, trybu oraz warunków prowadzenia działalności przez towarzystwa funduszy inwestycyjnych (Dz.U. poz. 538).

Sawicka, J., Stronczek, A. (2015). Postrzeganie roli audytu wewnętrznego w budowaniu zaufania publicznego jednostek - przykład banku. Studia Ekonomiczne. Zeszyty Naukowe Uniwersytetu Ekonomicznego w Katowicach, 244, 168-180.

Soh, D.S.B., Martinov-Bennie, N. (1986). The internal audit function: Perceptions of internal audit roles, effectiveness, and evaluation. Managerial Auditing Journal, 26 (7), 605-622.

Szczepankiewicz, E.I. (2011). The Role of the Audit Committee, the Internal Auditor and the Statutory Auditor as the Bodies Supporting Effective Corporate Governance in Banks. Zeszyty Naukowe Uniwersytetu Szczecinskiego, 640. Finanse, Rynki Finansowe, Ubezpieczenia, 38, 885-896.

Szczepankiewicz, E.I. (2012a). New Regulations and Internal Control System as supporting effective Corporate Governance in Commercial Banks in Poland. W: A.P. Balcerzak (red.), Banking and Financial Markets After Global Crisis of the Years 2008-2010 (s. 81-101). Torun: Nicolaus Copernikus University. Polish Economic Society Branch in Toruń.

Szczepankiewicz, E.I. (2012b). The role and tasks of the Internal Audit and Audit Committee as bodies supporting effective Corporate Governance in Insurance Sector Institutions in Poland. Oeconomia Copernicana, 4, 23 -39.

Szczepankiewicz, E.I. (2014). Zasady rachunkowości, kontrola wewnętrzna i audyt $w$ towarzystwach funduszy inwestycyjnych. Warszawa: CeDeWu.

Szczepankiewicz, E.I., Kiedrowska, M. (2011). Organizacja audytu wewnętrznego w zakładach ubezpieczeń w świetle Solvency II oraz standardów audytu. Prace Naukowe Uniwersytetu Ekonomicznego we Wrocławiu, $228,454-462$. 
Szczepankiewicz, E.I., Młodzik, E. (2016). Doskonalenie jakości audytu wewnętrznego w jednostkach sektora finansów publicznych. Finanse, Rynki Finansowe, Ubezpieczenia, 6/1 (84), 139-150. DOI: 10.18276/ fru.2016.84/1-12.

Ustawa z dnia 11 września 2015 r. o działalności ubezpieczeniowej i reasekuracyjnej (t.j. Dz.U. poz. 1844 z późn. $\mathrm{zm})$.

Ustawa z dnia 28 sierpnia 1997 r. o organizacji i funkcjonowaniu funduszy emerytalnych (t.j. Dz.U. 2016, poz. 1826).

Ustawa z dnia 29 sierpnia 1997 r. Prawo bankowe (t.j. Dz.U. 2016, poz. 1988).

Ustawa z dnia 7 grudnia 2000 r. o bankach spółdzielczych, ich zrzeszaniu się i bankach zrzeszających (t.j. Dz.U. 2016, poz. 1826).

Wróblewska, L. (2010). Osobowość i wartości etyczne audytora a jakość audytu według badań ankietowych przeprowadzonych w bankach. Zeszyty Naukowe Uniwersytetu Szczecińskiego. Finanse, Rynki Finansowe, Ubezpieczenia, 30 (2), 55-65.

Wytyczne do samooceny audytu wewnętrznego w jednostkach sektora finansów publicznych (2012). Warszawa: Departament Audytu Sektora Finansów Publicznych. Pobrane z: http://www.mf.gov.pl/c/document_library/get_ file?uuid=17d5d2e3-4bbd-4afa-8be2-14b4196bf4ca\&groupId=764034 (1.05.2017).

Wytyczne w zakresie programu zapewnienia i poprawy jakości (2012). Warszawa: Departament Audytu Sektora Finansów Publicznych. Pobrane z: http://www.mf.gov.pl/c/document_library/get_file?uuid=cde04f02-547c4018-a954-dbc653951 f02\&groupId=764034 (1.05.2017).

Zaleska, B. (2015). Ocena funkcjonowania zleconego audytu wewnętrznego w wybranych jednostkach samorządu terytorialnego województwa zachodniopomorskiego. Zeszyty Naukowe Uniwersytetu Szczecińskiego. Finanse, Rynki Finansowe, Ubezpieczenia, 76 (2), 89-98.

\section{DEVELOPMENT AND IMPROVEMENT OF INTERNAL AUDIT QUALITY IN PUBLIC INTEREST ENTITIES}

Abstract: Purpose - The article discusses the development and objectives of internal audit and improvement of its service quality in public interest entities.

Design/methodology/approach - Preparing the paper involved a review of literature, current law and regulations, and a critical analysis of internal documents and surveys carried out in the studied public interest entities. Findings - Results of questionnaire surveys on internal audit quality in selected units of public interest entities are presented.

Originality/value - The presented research results may serve as a hypothetical background for theorists for further advanced research into the measurement and improvement of internal audit quality in various entities.

Keywords: internal audit, quality of internal audit, public interest entities

\section{Cytowanie}

Szczepankiewicz, E.I. (2017). Rozwój i doskonalenie jakości audytu wewnętrznego w jednostkach zainteresowania publicznego. Finanse, Rynki Finansowe, Ubezpieczenia, 3 (87/1), s. 97-110. DOI: 10.18276/frfu.2017.87/ $1-09$. 